\title{
Nedim'in Meşhur Beytine Vakanüvis Es'ad Efendi'nin Şerhi
}

Yard. Doç. Dr. Ali Emre Özyıldırım*

Tanzimat öncesinde Türkçe manzum eserlere yazılmış şerhler birkaç istisnai örnek dişında edebî değil tasavvufî amaçlarla kaleme alınmıştır. Bu tip tasavvufî şerhler bir yana bırakılacak olursa bir Türkçe şiiri, edebî unsurlara da dikkat çekerek, izah etme gayretiyle yazılan en eski şerh örneklerinden birinin Bergamalı Kadrî'ye ait olduğunu söylemek mümkündür. Bergamalı Kadrî Anadolu Türkçesine ait ilk gramer kitabı niteliğindeki Müyessiretü'l-Ulûm (telifi: $937 \mathrm{H} .=1530$ M.)'un sonunda Hayâlî (ö. 964 H. = 1556-7 M.)'nin bir gazelini șerh etmiștir'. Arpaemini-zade Sâmî (ö. 1146 H. = 1733-4 M.)'nin

Ḥāżır ol bezm-i mükāfăta eyā mest-i gurūr Rahne-i seng-i siyeh penbe-i minādandır

beyti üzerine Müstakim-zâde Süleyman Saadeddin Efendi (ö. $1202 \mathrm{H}$. $=1787-8$ M.)'nin kaleme aldığı şerh (telifi: $1180 \mathrm{H}$. = 1766-7 M.) ise bu mısraları açıklama çabasıyla yazılan izah ve yorumların ilk örneği konumundadır ${ }^{2}$. 18. yüzyıl şairlerinden Ferrî (ö. $1220 \mathrm{H} .=1805$ M.)'nin kendi gazellerinden birine yazdığı șerh de bu konuda anılması gereken nâdir örneklerden biridir. ${ }^{3}$

\footnotetext{
*Anadolu Üniversitesi, Edebiyat Fakültesi Öğretim Üyesi

'Bergamalı Kadrî, Mïyessiretï̉'l-Ulîm, haz. Besim Atalay, İstanbul, 1946, s. $94-113$

${ }^{2}$ Müstaḳim-zāde Süleymān Sa'deddīn, "Şerḥ̣-i beyt", Mecmü‘a-i Resā 'il-i Müstaḳim-zāde, Dil ve Tarih-Coğrafya Fakültesi Ktp., M. Ozak I, 455, yk. 220a-b. Müstakim-zade burada beytin ilk mısraının aslında "Șaḳın ey mest-i derūn-saht ki rūz-ı ferdā" şeklinde olduğunu belirtmiștir.

${ }^{3}$ Mehmet Kırbıyık, "Ferrî Mehmed'in Bir Gazelinin Șerløine Dair”, Türkiyat Araștırmaları Dergrisi. Selçuk Üniversitesi Türkiyat Araştırmaları Enstitüsü, S. 7, Konya, 2000, s. 343-360.
} 
Süleymaniye Kütüphanesindeki Sahhaflarşeyhi-zade Vakanüvis Es'ad Efendi (ö. 1264 H. = 1848 M.)'ye ait mecmuaların birinde yer alan ve ilk defa bu yazıyla tanttılan Nedim (ö. $1143 \mathrm{H}$. = $1730 \mathrm{M}$.)'e ait meşhur beytin şerhi ise çeşitli açılardan kayda değer özelliklere sahiptir. Her șeyden önce bu șerh yukarıda da bahsedildiği gibi Tanzimat öncesinde tasavvufî değil de edebî kaygılarla kaleme alınan az sayıdaki örnekten biri olarak görünmektedir. Ayrıca aşağıda da görüleceği gibi Es'ad Efendi'nin, beyti şerh ederken bir anlamda yașadığı dönemde edebî bir tartışma başlatma niyetinde olduğu hissedilmektedir. Son olarak Es'ad Efendi'nin divan sahibi bir şair ve Türkçenin sadeleşmesi yolunda dönemine göre bilinçli gayretler sarf eden öncü isimlerden biri olması da yazdığı şerhin önemini artıran sebeplerden biri olarak düşünülmelidir ${ }^{4}$.

Așağıda önce Es'ad Efendi'nin şerhi verilmiş daha sonra bu șerh hakkındaki görüş ve yorumlarım sıralanmıştır.

"Ez-ġazel-i meşhür-1 Nedīm

Būy-1 gül taḳțir olunmuş ناز işlenmiş uc1

Biri olmuş ḩoy birisi dest-māl olmuş saña

Ekșer-i iḩvān-ı bā-șafã iş bu beyt-i dil-ārāda olan نازل lafẓında kāfı edāta ḥaml ile nāz u şive dinilen vaṣfi dest-māle teşbīh ile șüret-i isti āre-i tahyiliyyede gülüñ būyı takțîr olunup ve nāz u șivenüñ ucı işlenüp ya' ni naḳs olunup būy-1 güli gül-āb gibi hyoy-1 dil-bere ve nãzı clinde olan dest-māle teşbīh ile ma'nā virirler ise de istișmām-1 būy-1 fenn-i beyān edenlere hyafï degildir ki nāzıñ dest-māl ile vech-i şebehde münāsebeti yoḳdur. Evlāsı lafẓ-ı

\footnotetext{
${ }^{4}$ Es'ad Efendi için bkz:: Ziya Yılmazer, "Esad Efendi, Sahaflar Şcyhizade", TDViA. C. 11, Istanbul, 1995, s.341-345.
} 
mežkūr kāf ile bir kelime olarak lațif ma' nāsına olmaḳdır. Bu șūretde mahșūl-i beyt: Dil-beriñ ḩoyı ya'ní gül-i 'ižāında olan deri muḳațtar būy-1 gül ve gül dahi ețräfı naḳs olunmuş rūyunı silmege dest-māli oldı dimekdir." 5

Burada dikkat çeken ilk nokta söz konusu kelimenin "nāzıñ" değil de "nāzik" şeklinde okunması yolundaki teklifin Es'ad Efendi'ye ait olduğudur. Bizzat şârihin ifadelerinden, o dönemde de bu kelimenin "nâziñ" okunduğu ve beyte bugünkü gibi anlam verildiği gayet net olarak anlaşılmaktadır. Bununla beraber Es'ad Efendi'nin genel kabul gören okunuşa muhalefetle böyle bir teklifte bulunarak âdeta edebî bir tartışma başlatmaya çalışması acaba nasıl açıklanabilir? Bu iddianın sebebi ne olabilir? Şârihin teklifini edebî bir zemine oturtma gayreti ne kadar tatmin edicidir?

Her şeyden önce Es'ad Efendi'nin kelimeyi "nâzik" şeklinde okumasını nâzın dest-mâle istiare-i tahyîliyye yoluyla teşbih edilemeyeceğini, nâzın dest-mâl ile vech-i şebehde münasebetinin bulunmamasıyla açıklaması üzerinde durmak gerekir. "Sebk-i Hindî" ekolünün üslup özelliklerini başarıyla kullandığı bilinen bir şair olan Nedim'in, bu edebî anlayışın temel özelliklerinden biri olan soyut kavramları teşbih ve yine teşbihten ayrı düşünülmesi mümkün olmayan istiare yoluyla somutlaştırmanın Türk edebiyatındaki en başarılı ve sanatkârane örneklerini veren bir şair olduğu bilinmektedir. Nitekim üzerindè tartışılan beytin ilk mısraında "nâz" gibi soyut bir kavramın "ucunun işlenmesi" karinesiyle, yani istiare-i mekniyye-i tahyîliyye yoluyla "dest-mâl"e teşbihi ve ikinci mısrada müşebbehün bihin açığa çıkarılması, eğer bu hayâl orijinal ise, şairin muhayyile gücünü göstermesi bakımından en çarpıcı örneklerden

\footnotetext{
${ }^{5}$ Es`ad Efendi, Mecmī $a$, Süleymaniye Ktp. Esad Efendi $3737, y^{1}$. 1656 .
} 
biridir". Bu noktada şüphesiz Es'ad Efendi'nin, bir divan şairi olmasına rağmen, bu hayâli yakalayamadığını ve "nâz" ile "dest-mâl" arasında klișeleşmiş veya beklenen bir vech-i şebeh ilişkisi bulunmadığını ileri sürerek yeni arayışlara girdiğini ifade etmek gerekir. Kaldı ki beyitte söz konusu kelimenin "nāzıñ" şeklinde okunması gerektiğini 'ihsas' eden ve muhtemelen Es'ad Efendi'nin haberdar olmadığı bir edebî nükte daha vardır. Bu nükte ise "Bir kimsenin mendili olmak" diye tercüme edilebilecek Farsça "dest-mâli kesî bûden" deyiminde saklıdır. Bu deyimin bir kimsenin esiri, giriftarı, zebunu olmak anlamına geldiği düşünülürse ${ }^{7}$ beytin bütünlüğü içinde nâzın sevgilinin dest-mâli olması 'espri'si ve Nedim'in sanatkârlığı daha iyi anlaşılacaktır.

Acaba kelimenin "nāzik" olarak okunması beytin bütünlüğü içinde anlam ifade eder mi? Bu soruya da olumlu cevap vermek mümkün değildir. Es'ad Efendi'nin "mahsul-i beyt" başlığıyla verdiği son cümlesinden ucu işlenen nesnenin gül olduğunu iddia ettiği anlaşıllyor ki her şeyden önce bu durumda bir "za'f-1 telif" söz konusu olacaktır. Çünkü beyitte gülden değil bûy-1 gülden söz edilmektedir. Ayrıca böyle bir okuyuşta söz konusu "za'f-1 telif" in yanı sıra mısralar arasındaki çarpıcı paralellik de etkisini kaybedecektir. Nedim gibi usta bir şairin kaleminden çıkan beyitlerde bu kusurların bulunması düșünülemez.

Buradan hareketle edebiyat tarihimizle ilgili önemli bir tespitte bulunmak mümkündür. Es'ad Efendi'nin bu tutumu, yani soyut bir kavram olan "nâz"'n "dest-mâle" teşbihini kabul edememesi ve müşebbehin "gül" gibi somut bir nesne olması gerektiği yönündeki

\footnotetext{
"Divan edebiyatında bir șairin kullandığı edebî hayâlin "orijinalite"si hk.: Abdulkadir Gürer, "Şeyh Galib'in Şirlerinde Bir Anlatım Özelliği", Tiirkoloji Dergisi, C. 13, S. 1, s. 100-101, Ankara, 2000.

7 Rahịm 'Afïfĩ, Ferheng-nãme-i Si'rí, Sürûş̧, Tahran, 1372, C. 2, s, 981; "Dest-māl" kelimesinin kinaye yoluyla 'esir' anlamı taşıdığı da bilinmektedir: Mütercim 'Āṣım, Tibyānn-ı Nāfi' der-Terceme-i Burhānn-ı Kiat! $\iota^{\prime}$, İstanbul, 1265, s. 275.
} 
1srarı, özellikle İran edebiyatında "Sebk-i Hindî"ye yöneltilen, teşbih ve istiarelerdeki gariplik, tuhaflık gibi eleştirilerin, herhangi bir teorik tartışma zeminine oturtulmasa da potansiyel olarak divan edebiyatında da var olduğunu göstermektedir. Bunun temel sebebi ise biraz önce de değinildiği gibi söz konusu ekole mensup şairlerin kalıplaşmış teşbih unsurlarına iltifat etmeyerek daha önce örneği görülmeyen somutlaştırmalara gitmelerinde aranmalıdır. $\mathrm{Bu}$ tip hayâlleri anlayamayanlar Es'ad Efendi örneğinde görüldüğü gibi doğrudan eleştiride bulunmasalar da beyitleri farklı şekillerde okuyup anlamlandırmaya çalışarak bilinçli veya bilinçsiz bir şekilde söz konusu edebî ekole karşı bir tavır takınmışlardır. Şârihin beyti doğru okuyup, doğru anlamlandıranları "istişmâm-1 bûy-1 fenn-i beyân" edemeyenler olarak nitelemesini başka türlü açıklamak mümkün görünmemektedir. Halbuki en etkileyici örnekleri "Sebk-i Hindî'de görülen teşbih ve istiare yoluyla gerçekleştirilen alışılmamış somutlaştırmaların aslında üslup ve estetik açısından edebiyatta bir ilerleme olduğu rahatlıkla söylenebilir.

Divan edebiyatı üzerine yapılan çalış̧malarda bugüne kadar cn çok eksikliği hissedilen husus, şüphesiz üslup ve estetik merkezli çalışmaların kıtlığıdır. Bu konuda tatmin edici çalışmaların yapılabilmesinde divan şairlerinin birbirlerine yönelttikleri doğrudan veya bu yazıda söz konusu edilen dolaylı eleștirilerin önemini göz ardı etmek mümkün değildir. 